\title{
DEVELOPMENT OF STUDENT WORKSHEET BASED ON MEA MODEL OF IONIC EQUILIBRIUM AND PH OF BUFFER SOLUTION FOR SENIOR HIGH SCHOOL
}

\author{
Nelda*, Betty Holiwarni, and Lenny Anwar \\ Chemistry Education Study Program, FKIP Universitas Riau, Indonesia \\ *Email: neld.985@gmail.com
}

Accepted: January 20, 2022. Approved: January 23, 2022. Published: January 29, 2022

\begin{abstract}
This research aims to develop a Student Activities Worksheet Based on the MEA Model on the ionic equilibrium and $\mathrm{pH}$ of buffer solution material for grade XI SMA/MA. Student Worksheet Based are designed according to the stage of the MEA learning model. The type of this research is research and development ( $R$ and D) about the development process of 4-D. The object of this research is student activities worksheets based on MEA. The data collection is the validation user response questionnaire. The validity of the content aspect obtained the result of data analysis, characteristics of MEA, language aspect, serve aspect, and visual aspect are $96.43 \%, 93.33 \%, 85.41 \%, 97.22 \%, 97.91 \%$ with valid category. Student activities worksheets validated by the validators tested to 25 students and three teachers. The test responses by 25 students and three chemistry teachers included very good criteria, with each score of $95 \%$ and $80,33 \%$. Based on the result of data analysis, student activities worksheets based on MEA of ionic equilibrium and $\mathrm{pH}$ of a buffer solution produced are valid.
\end{abstract}

Keywords: Student Activities Worksheet, MEA model, Ionic Equilibrium and pH of Buffer Solution

\section{INTRODUCTION}

The world of education in Indonesia is currently facing challenges in preparing quality human resources to compete globally in the 21 st century. Of course, improving the quality of human resources can be done by improving the quality of education. Improving the quality of education is needed in producing human resources capable of facing the challenges of the $21 \mathrm{st}$ century. Therefore, the world of education is expected to conduct learning that supports 21 st-century skills, one of which is problem-solving skills [1].

The results obtained in a survey measuring students' problem-solving skills at PISA 2015 showed that of the 65 participating countries, Indonesia was ranked 61st. It indicates that the problem-solving skills of Indonesian students are still low [2]. Implementing less than optimal learning and not building problem-solving skills can be one of the causes of the low problemsolving skills of students [3].

One of the problems that are often found in the learning process is the limited use of teaching materials that can train students' problem-solving skills. Problem-solving skills are very important to be trained in the learning process and in everyday life, because problem solving skills are closely related to the real world so that they can be integrated to solve problems encountered in everyday life [4].

Based on the results of interviews with Chemistry teachers at SMAN 2 Pekanbaru, SMAN 6 Pekanbaru and MA Hasanah Pekanbaru, information was obtained that in the learning process teachers had used teaching materials, one of which was Students Worksheets. Based on observations, the Student Worksheets used by the teacher did not meet the requirements for making
Students Worksheets, i.e., didactic requirements, construction requirements and technical requirements [5]. The Student Worksheets used by the teachers are also not based on problem-solving learning models, are still informative, and contain only a summary of the material, practicum guides and practice questions. Therefore, the learnings conducted have not been able to train students' problem-solving skills.

One of the innovations that the researcher can do to overcome the problems found is to develop Student Worksheets based on the Means-Ends Analysis (MEA) model. MEA learning model is a variation of problem-solving based learning model with three learning stages: identification of current state and goal state, organization of subgoals, and determination of solutions [6]. The use of the MEA model based on problem-solving in the development of Student Worksheets can train students' problem-solving skills so that the learning conducted is able to build one of the 21 st century skills.

The results of previous studies related to the development of Mathematics learning tools in the MEA model based on a scientific approach to the subject of opportunities for high school students in Class $\mathrm{X}$ were valid with a valid Students Worksheets coefficient of 0.90 . The practicality of Students Worksheets is also efficient based on the teachers' and students' responses with $93.20 \%$ and $90.56 \%$ [7]. The purpose of this research is to develop teaching materials, especially Student Worksheets based on the MEA model on the subject of ionic equilibrium and $\mathrm{pH}$ of buffer solution for class XI SMA/MA, and to find out user responses from the developed Students Worksheets. 


\section{RESEARCH METHODS}

The research was conducted at the Chemical Education Study Program, Faculty of Teacher Training and Education, University of Riau, Pekanbaru, and tested at SMAN 2 Pekanbaru. Student Worksheets based on the MEA model on ionic equilibrium and $\mathrm{pH}$ of buffer solutions for
Class XI SMA/MA using a 4-D model consisting of the Define, Design, Develop and Disseminate stages [8]. The dissemination stage was not conducted because the research objective was only at the development of the Students Worksheets stage, which is valid based on aspects of content feasibility, MEA model characteristics, language, presentation, and graphics.

Table 1. MEA-Based Student Worksheets Development Flow on Ionic Equilibrium and pH of Buffer Solutions.

\begin{tabular}{|c|c|c|c|c|}
\hline \multirow[b]{2}{*}{ Define } & \multicolumn{4}{|c|}{$\begin{array}{c}\text { 1. Front-end analysis } \\
\text { 2. Analysis on Class XI SMA/MA Students } \\
\text { 3. task analysis }\end{array}$} \\
\hline & $\begin{array}{l}\text { 3.1. Content structure } \\
\text { analysis (analysis of } \\
\text { material of ionic } \\
\text { equilibrium and the pH of } \\
\text { buffer solutions on core } \\
\text { competencies, basic } \\
\text { competencies) }\end{array}$ & $\begin{array}{l}\text { 3.2. Material } \\
\text { concept analysis } \\
\text { of ionic } \\
\text { equilibrium and } \\
\text { the pH of buffer } \\
\text { solutions }\end{array}$ & $\begin{array}{l}\text { 3.3. Procedural analysis } \\
\text { * identification of current } \\
\text { state and goal state } \\
\text { * organization of sub } \\
\text { goals } \\
\text { * determination of } \\
\text { solution }\end{array}$ & $\begin{array}{l}\text { 3.4. analysis of } \\
\text { learning } \\
\text { objectives of } \\
\text { ionic equilibrium } \\
\text { and the pH of } \\
\text { buffer solutions }\end{array}$ \\
\hline
\end{tabular}

Design

4. Initial Design of Student Worksheets on ionic equilibrium and the $\mathrm{pH}$ of buffer solutions based on MEA

\section{Validation of 3 lecturer validators \\ Revision}

Develop

6. Product of Student Worksheets on ionic equilibrium and the $\mathrm{pH}$ of buffer solutions based on MEA

7. Limited Trials

Revision

Disseminate

The research data on the validity test and limited trial of the Student Worksheets based on the MEA model developed were obtained from the develop stage which includes the validation, revision and limited trial process using research instruments, i.e., validation sheets and student worksheets user response questionnaires.

Furthermore, a descriptive analysis of the research data was conducted to describe the value of the validation results on each aspect given by the validator. Likert scale is used for validation assessment and user response questionnaires. Each aspect of validity is determined by the percentage of the average score to determine the validity or feasibility of the developed Student Worksheets in the following way.

$$
\text { Percentage }=\frac{\text { Score obtained }}{\text { Maximum score }} \times 100 \%
$$

Then, it was converted into a qualitative value based on the percentage that has been obtained as shown in the following table.
8. Dissemination

Table 2. Validity Criteria [9]

\begin{tabular}{cc}
\hline Average Scores (\%) & User Response Criteria \\
\hline $80,00-100$ & Good/Valid/Feasible \\
$60,00-79,99$ & Good/Valid/Feasible \\
enough \\
$50,00-59,99$ & Less Good/Valid/Feasible \\
$0,00-49,99$ & $\begin{array}{c}\text { Not Good (must be } \\
\text { changed) }\end{array}$ \\
\hline
\end{tabular}

The average score of the user response test assessment, both teachers and students, was calculated as a percentage in the following way.

$$
\text { Percentage }=\frac{\text { Score obtained }}{\text { Maximum score }} \times 100 \%
$$

Then, it was converted into a qualitative value based on the percentage that has been obtained as shown in the following table. 
Table 3. User Response Criteria [10]

\begin{tabular}{cc}
\hline Average Scores (\%) & User Response Criteria \\
\hline $75,00-100$ & Very Good \\
$50,00-74,99$ & Good \\
$25,00-49,99$ & Less \\
$0,00-24,99$ & Not Good \\
\hline
\end{tabular}

\section{RESULTS AND DISCUSSION}

The product resulted from this development research is Student Worksheets based on MEA model on the subject of ionic equilibrium and $\mathrm{pH}$ of buffer solutions for class XI SMA/MA. The Student Worksheets can be used in the classroom during learning or as an independent learning resource for students. Results and discussion of the 3 stages of development that have been conducted are as follows.

\section{Define Stage}

The define stage begins with determining the fundamental problems in the learning process through front-end analysis. Front-end analysis was conducted through pre-research interviews with Chemistry teachers at SMAN 2 Pekanbaru, SMAN 6 Pekanbaru and MA Hasanah Pekanbaru. The basic problem found in the learning process was that the Student Worksheets used by the teacher had not been able to train students' problem-solving skills because the Student Worksheets used by the teacher were not based on a learning model. Thus, on the Students Worksheets, there was no procedure that guides students in solving problems. In addition, the Student Worksheets made by the teacher did not meet the requirements for making good Student Worksheets such as didactic, construction, and technical requirements [5].

The second analysis is the analysis of students. Students who studied the material of ionic equilibrium and the $\mathrm{pH}$ of buffer solutions are generally 16-17 years old. At this age, students are approaching maximum intellectual efficiency, however, lack of experience limits their knowledge and skills to utilize what they know [11]. Based on the results of interviews, students still had difficulty understanding the ionic equilibrium and the $\mathrm{pH}$ of the buffer solution materials, and the learning conducted at schools had not used a problemsolving-based learning model. Thus, learning or the use of teaching materials containing stages/steps of problem solving based on phenomena encountered by students in everyday life need to be familiarized so that they are trained in developing problemsolving skills in accordance with the demands of 21 st century learning. Buffer solution material is important to learn because it requires an understanding of concepts and chemical calculation that are used as a basis in solving problems [12]
The third analysis was a task analysis that begins with analyzing the structure of the content which includes core competencies, basic competencies and materials for ionic equilibrium and $\mathrm{pH}$ of the buffer solution contained in the syllabus for Chemistry subjects at SMA K13 2017 revised edition. Then, it is continued by analyzing the main concepts in ionic equilibrium material and the $\mathrm{pH}$ of the buffer solution (KD 3.12 and 4.12), arranged systematically in the form of a concept map. Furthermore, the task completion procedures used in the Student Worksheets were also analyzed. The stages of the MEA model used in the Student Worksheets were identification of current state and goal state, organization of subgoals, and determination of solutions. Finally, an analysis of learning objectives formulated based on the basic competencies was conducted (KD 3.12 and 4.12) which had been determined in the content structure analysis.

\section{Design Stage}

The Design of Students Worksheets produced Student Worksheets components which include cover, titles, usage instructions, basic competencies, study instructions, indicators of competency achievement, discourses containing problems on the subject of buffer solutions, MEA learning stages/activities, practice questions, assessment columns and bibliography .

At the design stage, an assessment instrument design was also produced in the form of validation sheets and user response test questionnaires (teachers and students), each of which was accompanied by an assessment rubric. There were five aspects of assessment in the design of the validation sheet to assess: the feasibility of the content, the characteristics of the MEA model, presentation, language, and graphics [13].

\section{Develop Stage}

The last stage in the development of these Students Worksheets is the develop stage. At this stage, validation and limited trials were conducted to determine the feasibility of the Students Worksheets and the developed Student Worksheets user response criteria.

Validation aims at obtaining assessments and suggestions for Student Worksheets based on MEA model on the material of ionic equilibrium and $\mathrm{pH}$ of buffer solutions by a material expert validator team consisting of 1 UR lecturer, 1 UIN SUSKA lecturer and 1 UMRI lecturer. The validation process was conducted twice. The data used was the results of the assessment on the second validation which was then analyzed based on each aspect of the validation [14]. The diagram of the average score of the second or final validation assessment for each aspect is presented in Figure 1. 


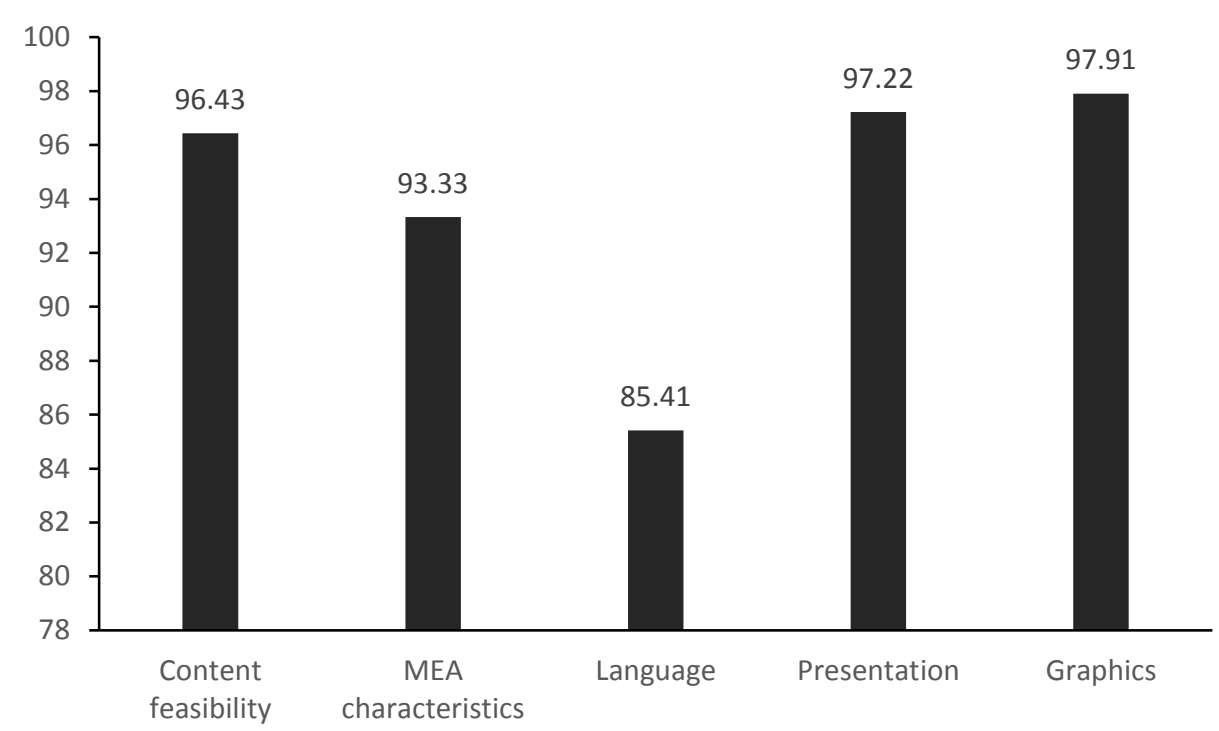

Figure 1. Average Score of Validation Assessment

The average total score for the five feasibility aspects is $94.06 \%$. The feasibility value is in the range of validity criteria of $80.00-100$ with a valid category, so a trial could be conducted.

Based on the validation results, the validators assessed that Student Worksheets based on MEA could help students in practicing problem-solving skills. Students' problem-solving skills can be trained and improved through the MEA learning process [15]. This is because the MEA learning process applies problem-solving procedures at each stage or step [16]. MEA learning begins with giving a problem in the form of a phenomenon, then students identify the information that is known and the purpose of solving the problem, then solve the problem until a solution is reached [17].

Students Worksheets that have been valid are then tested on users. The limited trials conducted included one-on-one trials and user response tests (teachers and students). One-on-one trials were conducted on 3 students who had different abilities. In the process, the three students need different times to complete the MEA-based Student Worksheets. Students, in general, could work on the stages of solving the MEA problems on the Student Worksheets, but there were some questions that were still answered wrong. This could be due to the fact that students were too hasty to work on the questions so that they were less thorough, and did not even re-check the answers that had been obtained [18].

The next trial was conducted on 3 high school Chemistry teachers and 25 students to find out the response of the Students Worksheets from the user side. In this trial, improvements were made according to suggestions and inputs obtained from users for the improvement of Students Worksheets.
The results of the teacher response test obtained an average score percentage of $95.83 \%$ with very good criteria and the test results to students obtained an average score percentage of $80.33 \%$ with very good criteria. Thus, the results of the limited trial were Students Worksheets has a very good response to be used for teachers and students during the learning process [19-20].

\section{CONCLUSION}

Student Worksheets based on the MEA model on ionic equilibrium and $\mathrm{pH}$ of the buffer solution for Class XI SMA/MA were declared valid by the validator with an average score of $94.06 \%$ from the five feasibility aspects in the valid category. Students Worksheets received a very good response from teachers and students with an average percentage of $95.83 \%$ by teachers and $80.33 \%$ by students. Thus, Student Worksheets based on the MEA model can be used in the learning process.

\section{REFERENCES}

[1] Martini, E. (2018). Membangun karakter generasi muda melalui model pembelajaran berbasis kecakapan abad 21.JPK (Jurnal Pancasila dan Kewarganegaraan), 3(2), 2127.

[2] Mariani, Y., \& Susanti, E. (2019). Kemampuan Pemecahan Masalah Siswa Menggunakan Model Pembelajaran Mea (Means Ends Analysis). Lentera Sriwijaya: Jurnal Ilmiah Pendidikan Matematika, 1(1), 13-26.

[3] Lailiyah, S., Kusaeri, K., \& Rizki, W. Y. (2020). Identifikasi proses berpikir siswa dalam menyelesaikan masalah aljabar dengan 
menggunakan representasi graf. Jurnal Riset Pendidikan Matematika, 7(1), 24-45.

[4] Cahyani, H., \& Setyawati, R. W. (2017, February). Pentingnya peningkatan kemampuan pemecahan masalah melalui PBL untuk mempersiapkan generasi unggul menghadapi MEA. In PRISMA, Prosiding Seminar Nasional Matematika (pp. 151-160).

[5] Ilham, I., Jufri, A. W., \& Lestari, N. (2020). Pengembangan Lembar Kerja Peserta Didik Model Inkuiri Berbantuan Multimedia Pada Materi Perubahan Lingkungan. Jurnal Pijar Mipa, 15(5), 515-520.

[6] Huda, M., \& Pd, M. (2014). Model-Model Pengajaran Dan Pembelajaran, Yogyakarta: Pustaka Pelajar. Kaelan, MS (2010). Pendidikan Kewarganegaraan. Yogyakarta: Paradigma, 2(3).

[7] Fitri, I., \& Aprilla, A. (2021). Pengembangan Lembar Kerja Siswa Berbasis Model Pembelajaran Means-Ends Analysis (MEA) Pada Materi Sistem Persamaan Linear Dua Variabel (SPLDV). JURING (Journal for Research in Mathematics Learning), 4(4), 309-318.

[8] Trianto, M. M. P. I. P. (2012). Konsep. Strategi, dan Implementasinya dalam KTSP, Jakarta: Bumi Aksara.

[9] Riduwan, M. D. (2012). Skala Pengukuran Variabel-variabel Penelitian. Bandung: Alfabeta.

[10] Lukitawati, P. (2017). Pengembangan Media Pembelajaran Matematika Berbasis ICT (Information and Communication Technology) Melalui Pendekatan SAVI (Somatic, Auditory, Visual, and Intellectual) Pada Materi Geometri Transformasi Kelas VII Di SMP Ma'had Islam Pekalongan. Delta: Jurnal Ilmiah Pendidikan Matematika, 2(2), 42-50.

[11] Indarwarti, A. (2018). Mengembangkan Kecerdasan Kognitif Anak Melalui Beberapa Metode. Psycho Idea, 15(2), 108-118.

[12] Rahayu, A. P., Ashadi, A., \& Saputro, S. (2014). Pembelajaran Kimia Menggunakan Metode Eksperimen dan Guided Inquiry Ditinjau dari Kemampuan Matematis dan Kreativitas Siswa. Inkuiri, 3(01).

[13] Rohani, A. (2014). Pengelolaan Pengajaran. Jakarta: Rineka Cipta

[14] Rasmiwetti, R., Nitasari, F., \& Anwar, L. (2020). Pengembangan Lembar Kegiatan Peserta Didik (LKPD) Berbasis Literasi Sains dengan Strategi Means-Ends Analysis (Mea) Pada Pokok Bahasan Asam dan Basa. Jurnal Pijar Mipa, 15(5), 488-492.

[15] Nurhadi, M. (2015). Pengaruh Strategi Means-Ends Analysis dalam Meningkatkan Kemampuan Penalaran Matematis dan SelfRegulated Learning Siswa SMP(Doctoral dissertation, Universitas Pendidikan Indonesia).

[16] Juanda, J., Johar, R. J., \& Ikhsan, M. I. (2014). Peningkatan Kemampuan Pemecahan Masalah dan Komunikasi Matematis Siswa SMP melalui Model Pembelajaran Meansends Analysis. Kreano, Jurnal Matematika Kreatif-Inovatif, 5(2), 105-113.

[17] Yulita, F. (2015). Kemampuan siswa memecahkan masalah melalui strategi Means Ends Analysis pada materi Differensial di kelas XI IPA MAN model Banda Aceh. Jurnal Peluang, 4(1).

[18] Lestari, P. (2016). Kemampuan pemecahan masalah siswa dengan penerapan PMRI pada materi kubus dan balok di SMP Negeri 17 Palembang. Skripsi. Inderalaya: FKIP UNSRI..

[19] Sugiyono, M. P. P., \& Kuantitatif, P. (2014). Kualitatif, dan R\&D, Bandung: Alfabeta. Cet. Vii.

[20] Rohani, A. (2004). Pengelolaan pengajaran. Jakarta: Rineka Cipta. 